\title{
Prawno-finansowe aspekty wykorzystania w Polsce odnawialnych źródeł energii w kontekście realizacji konstytucyjnej zasady zrównoważonego rozwoju
}

\section{Zagadnienia wstępne}

Wiodącą zasadą polskiej polityki ekologicznej jest przyjęta w Konstytucji RP² (dalej także w skrócie: Konst.) zasada zrównoważonego rozwoju, która została sformułowana w 1987 roku w tzw. Raporcie Brundtlanda Swiatowej Komisji do spraw Ochrony Środowiska i Rozwoju (ang. UNCED). Społeczność międzynarodowa uznała tę zasadę jako wzorzec rozwoju społeczno-gospodarczego i postępowania w sprawach dotyczących środowiska naturalnego w roku 1992, na Konferencji Narodów Zjednoczonych w Rio de Janeiro, przyjmując jednocześnie globalny program działania na XXI wiek w formie Agendy $21^{3}$. Podstawowym założeniem zrównoważonego rozwoju jest takie prowadzenie polityki i działań w poszczególnych sektorach gospodarki i życia społecznego, które prowadzi do zachowania zasobów i walorów środowiska naturalnego w stanie zapewniającym trwałe, nie doznające uszczerbku, możliwości korzystania z nich, zarówno przez obecne jak i przyszłe pokolenia, przy jednoczesnym zachowaniu trwałości funkcjonowania procesów przyrodniczych ${ }^{4}$ oraz naturalnej różnorodności biologicznej ${ }^{5}$. Istotą zrównoważonego rozwoju jest równorzędne traktowanie racji

1 Adiunkt w Katedrze Prawa Zarządzania Środowiskiem, Wydział Prawa, Prawa Kanonicznego i Administracji, Katolicki Uniwersytet Lubelski Jana Pawła II w Lublinie.

2 Art. 5 Konst.

3 Zob. L. MöLler, Znaczenie polityki ochrony środowiska z punktu widzenia przedsiębiorstw w aspekcie międzynarodowym, [w:] Międzynarodowe zarządzanie środowiskiem..., M.Kramer..., s.217 i n. oraz Agenda 21. Progress Report 1992-1998. Ind Updated Edition, Warsaw 1998.

4 Zob. szerzej A.Przyborowska-KLimCZaK, Ochrona przyrody. Studium prawnomiędzynarodowe, Lublin 2004, s.25 i n.

5 Por. P. Leroy, Political modernisation and the renewal of environmental policy arrangements, [w:] Sustainable development an european view, M.R. Dudzińska, A. Pawłowski, Lublin 2000, s.9 i n. 
społecznych, ekonomicznych i ekologicznych, co oznacza konieczność integrowania zagadnień ochrony środowiska z politykami w poszczególnych dziedzinach gospodarki ${ }^{6}$.

Zasada ta powinna wywierać wpływ na strategię realizacji zadań publicznych związanych z ochroną środowiska i stanowić ważne wskazanie dla decydentów. Przy podejmowaniu strategicznych decyzji o realizacji poszczególnych inwestycji należałoby większą uwagę przywiązywać do kwestii równoważenia racji ekonomicznych i społecznych, skłaniając się raczej ku mniejszemu rygoryzmowi w podejściu do efektów ekonomicznych i finansowych inwestycji, a większą wagę przypisując racjom społecznym i ekologicznym. Jest to na pewno trudne, w szczególności w Polsce, w okresie, gdy jednostki samorządu terytorialnego, tak jak cały sektor finansów publicznych, przeżywają problemy finansowe. Jednakże ekologia nie należy do wyborów łatwych. Można ją porównać do ochrony zdrowia, gdyż zarówno w ekologii, jak i też w ochronie zdrowia, należy mieć na uwadze to, że życie i zdrowie ludzkie, a także jakość życia ludzkiego, są kategoriami o statusie dobra najwyższej wartości, w stosunku do których nie można kierować się względami ekonomicznymi w takim stopniu, jak w odniesieniu do dóbr innej kategorii. W ocenie autora można przewidywać, że w niedalekiej przyszłości spór o charakter relacji ekonomicznych i środowiskowych w zakresie publicznych inwestycji proekologicznych, może się zaostrzyć. Konstatacja ta skłania ku poszukiwaniu, w ramach polityki ekologicznej państwa, nowej formuly kompromisu ekonomii z ekologią ${ }^{7}$, w zgodzie z zasadą zrównoważonego rozwoju.

Polityka ekologiczna kształtowała się w Polsce na przestrzeni ostatnich lat $\mathrm{w}$ zmieniającym się otoczeniu ustrojowym, prawnym, gospodarczym i finansowym ${ }^{8}$. Dokonujące się przemiany wywierały wpływ na sposób podejścia do ochrony środowiska, do systemu prawa ochrony środowiska ${ }^{9}$ i polityki ekologicz-

Zob. także D. MaśNIAK, Ubezpieczenia ekologiczne, Kraków 2003, s.21 i n.

7 Zob. na temat aktualnych problemów związanych $z$ wdrażaniem koncepcji zrównoważonego rozwoju: S. KozŁowski, Aktualne problemy zrównoważonego rozwoju, [w:] Filozoficzne i spoleczne uwarunkowania zrównoważonego rozwoju, A.Pawłowski (red.), Lublin 2003, s.99 i n. oraz Z. SADowski, Dezyderat trwatego rozwoju $i$ warunki jego spetnienia (tezy), [w:] Filozoficzne..., A.Pawłowski (red.)..., s. 13 i n.

8 Należy pamiętać przy tym o dorobku prawnym II Rzeczpospolitej Polskiej w zakresie prawa ochrony środowiska i kształtowania postaw proekologicznych w ówczesnym społeczeństwie i wśród przedsiębiorców, a także o toczącej się wówczas żywej dyskusji o kierunkach rozwoju polskiej ekologii. Zob. na ten temat np. A. Wodziczko, Ochrona przyrody wczoraj, dziś i jutro, Ochrona Przyrody, Nr 16/1936. Również zaraz po II wojnie światowej kwestie ochrony środowiska naturalnego znalazły swoich znamienitych propagatorów, chociażby w osobie W. Szafera. Zob. szerzej na ten temat: W. RADECKI, Samorząd terytorialny i ochrona środowiska. Przepisy z komentarzem, Warszawa 1991, s.13 i n.

9 Zob. szerzej L. GaRdjan-KaWA, Administrowanie zasobami środowiska po reformie ustrojowej, Warszawa 2000, s.13 in. 
nej ${ }^{10}$. J.Śleszyński zwraca uwagę na to, że ekonomiczne instrumenty polskiej polityki ochrony środowiska oparte są o ukształtowaną w latach siedemdziesiątych ubiegłego stulecia zasadę sprawcy i odpowiedzialności powszechnej. Wdrożenie takiego systemu odznaczało się w Polsce, jak i też w innych państwach gospodarki centralnie planowanej, niskim poziomem opłat ekologicznych, słabą restrykcyjnością systemu kar oraz niejasnym sprecyzowaniem sprawców i odpowiedzialności ${ }^{11}$.

Przemiany polityczno-ustrojowe i społeczno-gospodarcze w Polsce, na przełomie lat osiemdziesiątych i dziewięćdziesiątych XX wieku, stały się asumptem do sformułowania nowego podejścia do polityki ekologicznej. Było to zgodne z nurtem przemian gospodarczych i społecznych dokonujących się w całym regionie $^{12} .10$ maja 1991 roku Sejm RP podjął uchwałę aprobującą przyjętą rok wcześniej przez Radę Ministrów Politykę Ekologiczną Państwa ${ }^{13}$. Sformułowana wówczas polityka ekologiczna, nazwana później Pierwszą Polityką Ekologiczną Państwa (dalej także w skrócie: I PEP), stała się nie tylko deklaracją polityczną, ale również podstawą ustrojową dla programowania i realizacji przez administrację publiczną działań na rzecz ochrony środowiska. Dokument ten był również symbolem uczestnictwa Polski w nowoczesnym, międzynarodowym systemie ochrony środowiska. Dziesięć lat później, w roku 2000, w odpowiedzi na nowe wyzwania zmieniającej się rzeczywistości politycznej, ustrojowej i gospodarczej, została opracowana Druga Polityka Ekologiczna Państwa (dalej także w skrócie: II PEP), przyjęta przez Sejm w roku 2001 ${ }^{14}$. Następnie w roku 2002 przez Radę

10 Zob. szerzej M. Podolak, Polityka ekologiczna Polski w okresie transformacji, Lublin 2004, s. 37 in.

11 Zob. J. Śleszyński, Polityka ochrony środowiska w Polsce, [w:] Międzynarodowe zarządzanie srodowiskiem..., M.Kramer..., s..271 i n.

12 Zob. T. Ży LICZ, Z. Lehoczki, Towards Environmental Recovery. The Czech Republic-HungaryPoland-Slovakia, [w:] Changes in the Regional Economy in the Period of System Transformation, R.Domański, E.Judge, Warszawa 1994.

13 Zob. Uchwała Sejmu RP z dnia 10 maja 1991 roku w sprawie polityki ekologicznej państwa (Monitor Polski z 1991 r., Nr 18, poz. 118).

14 W literaturze przedmiotu zwraca się uwagę na fakt, że II PEP została przyjęta przez Radę Ministrów dnia 13 czerwca 2000 r., a następnie dnia 22 sierpnia 2001 r. uchwalona przez Sejm. Artykuł 10 ust. 2 ustawy $z$ dnia 27 lipca 2001 r. o wprowadzeniu ustawy Prawo ochrony środowiska, ustawy o odpadach oraz o zmianie niektórych ustaw (Dz.U. z 2001 r. Nr 100, poz.1085), nakazywał opracowanie nowej polityki ekologicznej, wyznaczając na to termin do 31 grudnia 2002 roku. Tymczasem II PEP uchwalona została jeszcze przed wejściem w życie ustawy z dnia 27 kwietnia 2001 roku Prawo ochrony środowiska (Dz.U.z 2001 r., Nr 62, poz.627 z późn.zm.). Zastanowienia wymaga więc, jak zauważa M.Bar, czy II PEP była w pełni zgodna $z$ wymogami wspomnianej ustawy. M.Bar zwraca uwagę na fakt, że II PEP obejmuje lata 2000 - 2025, gdy tymczasem zgodnie $z$ art. 14 ust. 2 ustawy Prawo ochrony środowiska politykę ekologiczną przyjmuje się na 4 lata, z tym, że przewidziane w niej działania w perspektywie obejmują kolejne 4 lata; zob. M.Bar, J.Boć, M.Bojarski, M.Górski, J.Jendrośka (red.) J.Jerzmański, E.Kaleta-Jagiełło, A.Lipiński, K.Nowicki, J.Rotko, W.Skarżyńska, T.Tatomir, Ustawa Prawo ochrony środowiska. Komentarz, Wrocław, 2001 r. Na temat charakte- 
Ministrów została opracowana Polityka ekologiczna państwa na lata 2003-2006 z uwzględnieniem perspektywy na lata $2007-2010^{15}$. Miała ona juź ściśle określony charakter prawny, wskazany w ustawie z dnia 27 kwietnia 2001 roku Prawo ochrony środowiska ${ }^{16}$ (dalej także w skrócie: u.p.o.ś), która wprowadziła obowiązek przygotowywania i aktualizowania co 4 lata polityki ekologicznej państwa ${ }^{17}$. Zgodnie z przepisami tej ustawy polityka ekologiczna państwa ma na celu stworzenie warunków niezbędnych do realizacji ochrony środowiska ${ }^{18}$, określając w szczególności: cele ekologiczne, priorytety ekologiczne, rodzaj i harmonogram działań proekologicznych, środki niezbędne do osiągnięcia celów, w tym mechanizmy prawno-ekonomiczne i środki finansowe.

Jednym z podstawowych celów polskiej polityki ekologicznej jest m.in. zmniejszanie energochłonności gospodarki, zarówno w odniesieniu do procesów wytwórczych, jak i też świadczenia usług oraz konsumpcji. Pomimo znaczącego zmniejszenia energochłonności wytwarzania dochodu narodowego w ostatnich latach, w ramach dotychczasowej polityki ekologicznej i restrukturyzacji gospodarczej ${ }^{19}$, wskaźnik ten jest w dalszym ciągu wyższy niż w pozostałych krajach Unii Europejskiej i OECD. Podstawowe założenia polityki energetycznej państwa przewidują, że w związku z dalszym urealnianiem cen energii, postępem w modernizacji i restrukturyzacji działalności gospodarczej oraz wzrostem świadomości społecznej sprzyjającej oszczędzaniu energii, zużycie energii w przeliczeniu na jednostkę krajowego produktu będzie się nadal zmniejszać. Do 2010 roku spadek ten powinien wynieść ok. 25\% w stosunku do roku 2000. Działaniom w zakresie zmniejszania energochłonności musi towarzyszyć kontynuowanie przedsięwzięć zmieniających sposób zaspokajania istniejących potrzeb energetycznych, przede wszystkim w odniesieniu do struktury wykorzystania nośników energii, w kierunku dalszego zwiększania udziału energii elektrycznej w ogólnym zużyciu energii finalnej (a zmniejszania finalnego zużycia energii pochodzącej bezpośrednio ze spalania paliw), zwiększania udziału w produkcji energii gazu i ropy naftowej (w miejsce węgla), poprawy jakości węgla i innych paliw, a także

ru prawnego polityki ekologicznej zobacz także: E. Radziszewski, Prawo ochrony środowiska. Przepisy $i$ komentarz, Warszawa 2003.

15 Zob. Uchwała Sejmu RP z dnia 8 maja 2003 r. w sprawie przyjęcia Polityki Ekologicznej Państwa na lata 2003-2006 z uwzględnieniem perspektywy na lata 2007-2010 (MP z 2003 r., Nr 33, poz.433). Wcześniej, w dniu 17 grudnia 2002 roku, dokument ten przyjęła Rada Ministrów.

16 Ustawa $z$ dnia 27 kwietnia 2001 r. Prawo ochrony środowiska (Dz.U.z 2001 r. Nr 62, poz.627 z póżn.zm.).

17 Zob. na temat prawnego charakteru polityki ekologicznej państwa: J.Jendrośka (red.), Ustawa Prawo ochrony środowiska. Komentarz, Wrocław 2001

18 Art.13 u.p.o.ś.

19 Wskaźnik energchłoności wytwarzania dochodu narodowego brutto udało się zmniejszyć w latach 1990-2000 z ponad 2 ton oleju ekwiwalentnego / 1 tys. USD PKB do ok. 1,2 tony / 1 tys. USD PKB. 
wzrostu udziału w produkcji energii elektrycznej i cieplnej energetycznych nośników odnawialnych ${ }^{20}$.

Ochrona powietrza przed zanieczyszczeniami jest najbardziej wraźliwym społecznie kierunkiem działań w ochronie środowiska, gdyż na niej koncentruje się uwaga zarówno społeczności lokalnych i przedsiębiorców, jak i też społeczności międzynarodowej, ze względu na bezpośrednie oddziaływanie zanieczyszczeń powietrza na zdrowie ludzkie, a także ze względu na przenoszenie tych zanieczyszczeń na dalekie odległości, oddziaływanie na zmiany klimatu i wywoływanie niekorzystnych procesów w warstwie ozonowej. Charakterystycznymi cechami polityki w zakresie ochrony powietrza przed zanieczyszczeniami są m.in.: (1) zwiększenie liczby zanieczyszczeń objętych przeciwdziałaniem mającym zmniejszyć lub ograniczyć ich emisję i niekorzystne oddziaływanie na środowisko; (2) konsekwentne przechodzenie na likwidację zanieczyszczeń u źródła, poprzez zmiany nośników energii (ze szczególnym uwzględnieniem źródeł energii odnawialnej), stosowanie czystszych surowców i technologii oraz minimalizację zużycia energii i surowców.

W średniookresowym horyzoncie czasowym (do roku 2010), zgodnie z wytycznymi II PEP należy zrealizować m.in. następujące cele: (1) ograniczyć emisję pyłów średnio o $75 \%$, dwutlenku siarki o $56 \%$, tlenków azotu o $31 \%$, lotnych związków organicznych (poza metanem) o $4 \%$ i amoniaku o $8 \%$, w stosunku do stanu w 1990 roku; (2) ograniczyć emisję toksycznych substancji z grupy metali ciężkich (rtęć, ołów, kadm) i trwałych zanieczyszczeń organicznych (pestycydy, benzo(a)piren i dioksyny), a także wycofać z produkcji i użytkowania bądź ograniczyć użytkowanie produktów zawierających te toksyczne substancje; (3) osiągnąć w latach 2008-2012 wielkość emisji gazów cieplarnianych nie przekraczającą 94\% wielkości emisji z roku 1988; (4) dwukrotnie zmniejszyć w stosunku do stanu z 1990 roku energochłonność dochodu narodowego oraz szeroko wprowadzić najlepsze dostępne techniki z zakresu efektywności energetycznej i użytkowania odnawialnych źródeł energii.

W perspektywie długookresowej (do roku 2025) priorytetowe kierunki polityki ekologicznej w zakresie ochrony powietrza obejmują m.in.: (1) zasadniczą przebudowę modelu produkcji i konsumpcji w kierunku poprawy efektywności energetycznej i surowcowej, szerszego wykorzystania odnawialnych źródeł energii oraz minimalizacji emisji zanieczyszczeń do powietrza przez wszystkie podstawowe rodzaje źródeł; (2) pełną realizację zobowiązań dotyczących wyeliminowania lub ograniczenia produkcji i użytkowania wszystkich substancji i produktów zawierających niebezpieczne zanieczyszczenia powietrza, wynikających z wymogów międzynarodowych.

20 Zob. szerzej M. DzIUBiśski, Rola odnawiahych źródeł energii w zrównoważonym rozwoju kraju, [w:] Ochrona środowiska, wybrane zagadnienia, B. Kozłowska (red.), Łódź 2001, s. III-1 i n. 
II PEP formułując cele w odniesieniu do jakości powietrza pośrednio nakłada na jednostki samorządu terytorialnego obowiązek realizacji określonych inwestycji, których celem będzie przede wszystkim dostosowanie komunalnych instalacji elektro-energetycznych do wymagań i norm UE oraz do norm międzynarodowych, głównie w zakresie standardów emisji zanieczyszczeń i odpowiedniego udziału odnawialnych źródeł energii w bilansie energetycznym poszczególnych podmiotów produkujących energię cieplną i elektryczną.

\section{Prawno-finansowe podstawy wykorzystania odnawialnych źródeł energii}

Dnia 10 kwietnia 1997 roku Sejm uchwalił ustawę Prawo energetyczne ${ }^{21}$ (dalej także w skrócie: $u$.p.e.), kończąc tym samym okres wieloletnich prac legislacyjnych zmierzających do wprowadzenia daleko idących zmian w sektorze energetycznym. O doniosłym znaczeniu tej ustawy dla sektora energetycznego i dla realizacji polityki ekologicznej świadczą przede wszystkim jej przepisy obejmujące zakresem swego oddziaływania miliony odbiorców paliw i energii. Obowiązkiem jej stosowania objęte są także organy administracji rządowej, jednostki samorządu terytorialnego i przedsiębiorcy prowadzący działalność gospodarczą w sektorze energetycznym.

Prawo energetyczne nakazuje uwzględniać tematykę odnawialnych źródeł energii w dokumentach planistyczno-strategicznych odnoszących się do sektora energetycznego. Artykuł 14 pkt 6 u.p.e. stanowi, że polityka energetyczna państwa określa m.in. rozwój wykorzystania odnawialnych źródeł energii ${ }^{22}$. Również w lokalnej polityce energetycznej istotną rolę winna odgrywać energetyka odnawialna. W myśl art. 19 u.p.e. wójt (burmistrz, prezydent miasta) opracowując projekt założeń do planu zaopatrzenia w ciepło, energię elektryczną i paliwa gazowe, powinien w nim uwzględnić m.in. możliwości wykorzystania istniejących nadwyżek i lokalnych zasobów paliw i energii, z uwzględnieniem energii elektrycznej i ciepła wytwarzanych w odnawialnych źródłach energii, energii elek-

21 Ustawa z dnia 10 kwietnia 1997 r. Prawo energetyczne (tekst pierw. Dz. U. 1997 r. Nr 54 poz. 348, tekst jedn. Dz. U. 2003 r. Nr 153 poz. 1504) znowelizowana została w szerszym zakresie w 2005 roku ustawą z dnia 4 marca 2005 r. o zmianie ustawy - Prawo energetyczne oraz ustawy - Prawo ochrony środowiska (Dz.U. z 2005 r. Nr 62, poz. 552).

22 Polityka energetyczna państwa czy też Strategia Rozwoju Energetyki Odnawialnej stanowią tzw. akty kierownictwa wewnętrznego i nie posiadają mocy prawa powszechnie obowiązującego. Zob. szerzej na ten temat B. Kudrycka, P. Sitniewski [w:] Wielka encyklopedia prawa, E. Smoktunowicz (red.), Białystok - Warszawa 2000, s. 39. Szerzej na temat polityki energetycznej zob także A. WaLASzEK-PyzIOL, Ksztaltowanie i realizacja polityki energetycznej państwa na gruncie ustawy.Prawo energetyczne, podmioty, instrumenty, [w:] Administracja Publiczna w państwie prawa. Ksiega jubileuszowa dla prof. J. Jendrośki, Wrocław 1999. 
trycznej wytwarzanej w skojarzeniu z wytwarzaniem ciepła oraz zagospodarowania ciepła odpadowego $\mathrm{z}$ instalacji przemysłowych. $Z$ kolei zgodnie $\mathrm{z}$ art. 16 u.p.e. przedsiębiorstwa energetyczne zajmujące się przesyłaniem lub dystrybucją paliw gazowych lub energii sporządzają dla obszaru swojego działania plany rozwoju w zakresie zaspokojenia obecnego i przyszłego zapotrzebowania na paliwa gazowe lub energię, uwzględniając miejscowy plan zagospodarowania przestrzennego albo kierunki rozwoju gminy określone w studium uwarunkowań i kierunków zagospodarowania przestrzennego gminy. Plany rozwoju powinny obejmować m.in. przedsięwzięcia w zakresie modernizacji, rozbudowy albo budowy sieci oraz ewentualnych nowych źródeł paliw gazowych, energii elektrycznej lub ciepła, w tym źródeł odnawialnych.

Do odnawialnych źródeł energii bezpośrednie zastosowanie, o dużym znaczeniu praktycznym, ma przepis art. 32 u.p.e. stanowiący, że uzyskania koncesji wymaga wykonywanie działalności gospodarczej w zakresie wytwarzania paliw lub energii, z wyłączeniem: wytwarzania paliw stałych lub paliw gazowych, wytwarzania energii elektrycznej w źródłach o łącznej mocy nieprzekraczającej 50 MW niezaliczanych do odnawialnych źródeł energii, wytwarzania energii elektrycznej w skojarzeniu z wytwarzaniem ciepła w źródłach o łącznej mocy nieprzekraczającej $5 \mathrm{MW}$ niezaliczanych do odnawialnych źródeł energii, wytwarzania ciepła w źródłach o łącznej mocy nieprzekraczającej 5MW'23.

$\mathrm{Z}$ punktu widzenia rozwoju energetyki odnawialnej kluczowy jest jednakże zapis artykułu 9a u.p.e., zgodnie z którym przedsiębiorstwo energetyczne zajmujące się wytwarzaniem energii elektrycznej lub jej obrotem i sprzedające tę energię odbiorcom, którzy dokonują jej zakupu na własne potrzeby na terytorium Rzeczypospolitej Polskiej, jest obowiązane, w zakresie określonym w przepisach wykonawczych do ustawy, do: (1) zakupu energii elektrycznej wytworzonej w odnawialnych źródłach energii lub (2) wytworzenia energii elektrycznej we własnych odnawialnych źródłach energii znajdujących się na terytorium Rzeczypospolitej Polskiej i przyłączonych do sieci.

Warto pamiętać, że ustawa z dnia 24 lipca 2002 r. nowelizująca Prawo energetyczne ${ }^{24}$ wprowadziła zmianę definicji odnawialnych źródeł energii ${ }^{25}$. Zgodnie $\mathrm{z}$ art. 3 pkt 20 u.p.e. odnawialne źródło energii jest to źródło wykorzystujące $\mathrm{w}$ procesie przetwarzania energię wiatru, promieniowania słonecznego, geotermalną, fal, prądów i pływów morskich, spadku rzek oraz energię pozyskiwaną

23 Zob. na ten temat L. KARski, Koncesja a energetyka odnawialna, Czysta Energia, Nr 9/2003.

24 Ustawa z dnia 24 lipca 2002 r. o zmianie ustawy - Prawo energetyczne (Dz.U. z 2002 r. Nr 135, poz. 1144).

25 Szerzej na temat terminologii energetyki odnawialnej zob.: L. KARsKI, Energetyka odnawialna $w$ znowelizowanej ustawie, podstawowe definicje i terminy, Czysta Energia, Nr 4/2003 oraz L. KARski, System wsparcia energetyki odnawialnej w znowelizowanej ustawie Prawo energetyczne, Prawo i Srodowisko, Nr 2/2003. 
z biomasy, biogazu wysypiskowego, a także biogazu powstałego w procesach odprowadzania lub oczyszczania ścieków albo rozkładu składowanych szczątek roślinnych i zwierzęcych.

Szczegółowy zakres obowiązków w zakresie zakupu energii elektrycznej wytworzonej w odnawialnych źródłach energii oraz wytworzenia energii elektrycznej we własnych odnawialnych źródłach energii znajdujących określa rozporządzenie Ministra Gospodarki i Pracy z dnia 9 grudnia 2004 r.w sprawie szczegółowego zakresu obowiązku zakupu energii elektrycznej i ciepła wytworzonych w odnawialnych źródlach energii ${ }^{26}$. Zgodnie $\mathrm{z} \$ 10$ powołanego rozporządezenia obowiązek, o którym mowa w art. 9a ust. 1 ustawy Prawo energetyczne, uznaje się za spełniony, jeżeli udział ilościowy zakupionej energii elektrycznej wytworzonej w odnawialnych źródłach energii lub wytworzonej we własnych odnawialnych źródłach energii i sprzedanej odbiorcom dokonującym zakupu energii elektrycznej na własne potrzeby, w wykonanej całkowitej rocznej sprzedaży energii elektrycznej przez dane przedsiębiorstwo energetyczne tym odbiorcom, wynosi nie mniej niż: $3,1 \%$ - w 2005 r.; 3,6 \% - w 2006 r.; 4,3 \% - w 2007 r.; 5,4 \% - w 2008 r.; 7,0 \% - w 2009 r.; 9,0 \% - w 2010 r.; 9,0 \% - w 2011 r.; 9,0 \% - w 2012 r.; 9,0 \% - w 2013 r.; 9,0 $\%$ - w 2014 roku. Obowiązek, o którym mowa w art. 9a ust. 3 ustawy, uznaje się za spełniony, jeżeli oferowane do sprzedaży ciepło, wytworzone w odnawialnych źródłach energii, zakupiono w ilości w jakiej je oferowano lub równej zapotrzebowaniu odbiorców przedsiębiorstwa energetycznego realizującego ten obowiązek i przyłączonych do sieci ciepłowniczej, do której jest przyłączone odnawialne źródło energii, proporcjonalnie do udziału tego źródła w całkowitej mocy zamówionej przez odbiorców, z uwzględnieniem charakterystyki odbioru oraz możliwości przesyłania ciepła wytwarzanego w tym źródle.

Przedsiębiorstwa energetyczne są zobowiązane corocznie do zakupu tzw. zielonej energii na wyżej określonym poziomie procentowym w stosunku do całkowitej rocznej sprzedaży energii elektrycznej w danym przedsiębiorstwie. Za niewypełnienie tego obowiązku grozi, zgodnie z Prawem energetycznym, kara w wysokości do $15 \%$ uzyskanego przychodu przedsiębiorstwa i do $300 \%$ miesięcznego wynagrodzenia kierownika przedsiębiorstwa. Część przedsiębiorstw energetycznych ma jednakże problemy z wywiązaniem się z obowiązków ustawowych. Wynika to zarówno z niedostatecznej podaży zielonej energii na rynku, jak i też z występującym, trudnym do rozwiązania problemem wielokrotnego obrotu tą energią, co w praktyce oznacza, że ta sama energia jest kilkakrotnie sprzedawana pośrednikom zanim trafi do spółki bezpośrednio obsługującej odbiorców ${ }^{27}$. W przypadku, gdy więcej

26 Rozporządzenie Ministra Gospodarki i Pracy z dnia 9 grudnia 2004 r.w sprawie szczegółowego zakresu obowiązku zakupu energii elektrycznej i ciepła wytworzonych w odnawialnych źródłach energii (Dz.U.2004 r. Nr 267 poz 2656).

27 J. WRóBEL, Energetyka. Deficyt energii ze źródeł odnawialnych uniemozliwia wypelnienie obowiązkowych limitów.Zakup zielonej energii pod groźbq kary, Gazeta Prawna z 28.10.2003 r. 
niż jedno przedsiębiorstwo energetyczne zajmuje się obrotem ciepłem i sprzedaje to ciepło odbiorcom przyłączonym do połączonych i współpracujących ze sobą sieci ciepłowniczych, obowiązek zakupu dotyczy ciepła wytworzonego w przyłączonych do tych sieci odnawialnych źródłach energii, w ilości proporcjonalnej do udziału każdego $\mathrm{z}$ tych przedsiębiorstw w lącznej sprzedaży ciepła przez wszystkie przedsiębiorstwa energetyczne dostarczające ciepło do odbiorców przyłączonych do tych sieci. Zgodnie z przepisami powołanego rozporządzenia koszty uzasadnione zakupu energii elektrycznej lub ciepła, ponoszone w związku z realizacją obowiązków uwzględnia się w kalkulacji cen ustalanych w taryfach przedsiębiorstw energetycznych realizujących te obowiązki, przyjmując, że: (1) jednostka energii elektrycznej, sprzedawana przez dane przedsiębiorstwo energetyczne wszystkim odbiorcom, jest w tej samej wysokości obciążona tymi kosztami; (2) koszty te obciążają w tej samej wysokości jednostkę ciepła sprzedawanego przez dane przedsiębiorstwo energetyczne wszystkim odbiorcom przyłączonym do sieci ciepłowniczej, do której jest przyłączone odnawialne źródło energii. Kosztami uwzględnianymi w taryfach są koszty zakupu: (1) energii elektrycznej na giełdzie towarowej w rozumieniu przepisów ustawy z dnia 26 października 2000 r. o giełdach towarowych; (2) energii elektrycznej na pozagiełdowym, ogólnodostępnym rynku konkurencyjnym; (3) energii elektrycznej lub ciepła na podstawie ceny ustalonej odpowiednio w: (a) zatwierdzonej przez Prezesa Urzędu Regulacji Energetyki taryfie albo (b) wyniku przetargu lub negocjacji w przypadku, gdy taryfa nie podlega zatwierdzeniu przez Prezesa Urzędu Regulacji Energetyki. Jako koszty energii elektrycznej, ponoszone w związku z realizacją obowiązku zakupu energii ze źródeł odnawialnych uznaje się także koszty uzasadnione wytwarzania tej energii we własnych źródłach odnawialnych. Rozporządzenie, o którym mowa określa szczegółowy zakres obowiązku zakupu energii elektrycznej i ciepła wytworzonych w odnawialnych źródłach energii, w tym: (1) rodzaje odnawialnych źródeł energii; (2) parametry techniczne i technologiczne wytwarzania energii elektrycznej lub ciepła z odnawialnych źródeł energii; (3) wymagania dotyczące pomiarów, rejestracji i sposobu obliczania ilości energii elektrycznej lub ciepła wytwarzanych w odnawialnych źródłach energii za pomocą instalacji wykorzystujących w procesie wytwarzania energii odnawialne nośniki energii oraz inne paliwa; (4) wielkość i sposób obliczania udziału energii elektrycznej wytwarzanej w odnawialnych źródłach energii, do której zakupu lub wytworzenia przedsiębiorstwo energetyczne jest obowiązane, w sprzedaży energii elektrycznej, w okresie kolejnych 10 lat; (5) sposób uwzględniania w kalkulacji cen energii elektrycznej i ciepła, ustalonych w taryfach przedsiębiorstw energetycznych, kosztów zakupu lub wytworzenia energii elektrycznej i ciepła, do których zakupu lub wytworzenia przedsiębiorstwo to jest obowiązane.

Zgodnie $\mathrm{z}$ definicjami przyjętymi w rozporządzeniu: (1) biomasa - są to stałe lub ciekłe substancje pochodzenia roślinnego lub zwierzęcego, które ulegają biodegradacji, pochodzące z produktów, odpadów i pozostałości z produkcji rolnej 
oraz leśnej, a także przemysłu przetwarzającego ich produkty, a także części pozostałych odpadów, które ulegają biodegradacji; (2) biogaz - jest to gaz pozyskany z biomasy, w szczególności z instalacji przeróbki odpadów zwierzęcych lub roślinnych, oczyszczalni ścieków oraz składowisk odpadów; (3) mieszane paliwo wtórne - to paliwo będące mieszanką biomasy lub biogazu oraz innych paliw, przygotowane poza jednostką wytwórczą zużywającą to paliwo; (4) jednostka wytwórcza - jest to opisany przez dane techniczne i handlowe wyodrębniony zespół urządzeń należących do przedsiębiorstwa energetycznego, służący do wytwarzania energii elektrycznej lub ciepła i wyprowadzenia mocy; (5) układ hybrydowy - jest to jednostka wytwórcza wytwarzająca energię elektryczną albo energię elektryczną i ciepło, w której w procesie wytwarzania energii elektrycznej lub ciepła wykorzystywane są nośniki energii wytwarzane oddzielnie w odnawialnych źródłach energii i w źródłach energii innych niż odnawialne oraz zużywane wspólnie w tej jednostce wytwórczej do wytworzenia energii elektrycznej lub ciepła.

Do energii wytwarzanej w odnawialnych źródłach energii zalicza się, niezależnie od mocy źródła, energię elektryczną lub ciepło pochodzące w szczególności: (1) z elektrowni wodnych oraz wiatrowych; (2) ze źródeł wytwarzających energię $z$ biomasy oraz biogazu; (3) ze słonecznych ogniw fotowoltaicznych oraz kolektorów do produkcji ciepła; (4) ze źródeł geotermalnych. W jednostce wytwórczej, w której są spalane biomasa lub biogaz wspólnie z innymi paliwami, do energii wytwarzanej w odnawialnych źródłach energii zalicza się część energii elektrycznej lub ciepła odpowiadającą procentowemu udziałowi energii chemicznej biomasy lub biogazu w energii chemicznej paliwa zużywanego do wytwarzania energii, obliczaną na podstawie rzeczywistych wartości opałowych tych paliw. Pomiary, rejestracja oraz sposób obliczania ilości energii elektrycznej lub ciepła wytwarzanych w odnawialnych źródłach energii powinny być wykonywane zgodnie z procedurą pomiarów, rejestracji i obliczania ilości energii wytworzonej w odnawialnych źródłach energii, opracowaną dla danej jednostki wytwórczej przez przedsiębiorstwo energetyczne. Przedsiębiorstwo energetyczne stosując do wytwarzania energii elektrycznej lub ciepła mieszane paliwo wtórne, powinno: (1) wykonać pomiary masy mieszanego paliwa wtórnego dostarczonego do procesu spalania w jednostce wytwórczej; (2) oznaczyć ciepło spalania i wykonać obliczenia wartości opałowej: (a) mieszanego paliwa wtórnego dostarczanego do procesu spalania w jednostce wytwórczej,(b) próbek paliw wchodzących w skład paliwa wtórnego, (3) udokumentować udział energii chemicznej biomasy lub biogazu w energii chemicznej mieszanego paliwa wtórnego. Parametry techniczne i technologiczne wytwarzania energii elektrycznej w odnawialnych źródłach energii powinny umożliwiać współpracę z siecią, zgodnie z parametrami technicznymi energii elektrycznej przesyłanej tą siecią oraz zgodnie z odrębnymi przepisami. Parametry techniczne i technologiczne wytwarzania ciepła w odna- 
wialnych źródłach energii powinny być dostosowane do parametrów nośnika ciepła oraz warunków pracy sieci ciepłowniczej i potrzeb odbiorców, zgodnie $\mathrm{z}$ odrębnymi przepisami.

Zgodnie $z$ art. 9a ustawy Prawo energetyczne przedsiębiorstwo energetyczne zajmujące się wytwarzaniem energii elektrycznej lub jej obrotem i sprzedające tę energię odbiorcom, którzy dokonują jej zakupu na własne potrzeby na terytorium Polski, jest obowiązane, w zakresie określonym w przepisach wykonawczych do ustawy, do zakupu oferowanej energii elektrycznej wytworzonej w skojarzeniu $\mathrm{z}$ wytwarzaniem ciepła w przyłączonych do sieci źródłach energii znajdujących się na terytorium Polski. Przedsiębiorstwo energetyczne zajmujące się obrotem ciepłem i sprzedające to ciepło, jest obowiązane, w zakresie określonym w przepisach wykonawczych do ustawy, do zakupu oferowanego ciepła wytwarzanego w przyłączonych do sieci odnawialnych źródłach energii znajdujących się na terytorium Rzeczypospolitej Polskiej, w ilości nie większej niż zapotrzebowanie odbiorców tego przedsiębiorstwa, przyłączonych do tej sieci, do której przyłączone są odnawialne źródła energii. Przedsiębiorstwo energetyczne zajmujące się przesyłaniem lub dystrybucją energii elektrycznej, do którego sieci są przyłączone odnawialne źródła energii, jest obowiązane do odbioru całej ilości energii elektrycznej wytworzonej w tych źródłach, objętej zgłoszonymi do tego przedsiębiorstwa przez wytwórcę tej energii umowami sprzedaży.

Kwestie pośrednio związane $\mathrm{z}$ odnawialnymi źródłami energii uregulowane są także w ustawie prawo ochrony środowiska, chociaż z punktu widzenia inwestycji komunalnych w sektorze energetycznym kluczowe są przytoczone wyżej zapisy prawa energetycznego. Bardzo ważne dla rozwoju odnawialnych źródeł energii jest promowanie przez prawo ochrony środowiska stosowania najlepszych dostępnych technik, przez co rozumie się najbardziej efektywny oraz zaawansowany poziom rozwoju technologii i metod prowadzenia danej działalności, wykorzystywany jako podstawa ustalania granicznych wielkości emisyjnych, mających na celu eliminowanie emisji lub, jeżeli nie jest to praktycznie możliwe, ograniczanie emisji i wpływu na środowisko jako całośćc ${ }^{28}$. Najlepsze dostępne techniki stanowią realizację strategii przeciwdziałania zanieczyszczeniom. Istota zasady prewencji zawiera się $w$ tym, iż przeciwdziałanie negatywnym skutkom dla środowiska powinno być podejmowane na etapie planowania i realizacji przedsięwzięć w oparciu o posiadaną wiedzę, wdrożone procedury ocen oddziaływania na środowisko oraz monitorowanie prowadzonych przedsięwzięć. Takiemu podejściu sprzyja energetyka odnawialna, której rozwój ma istotne znaczenie w działaniu na rzecz przebudowy modelu produkcji i konsumpcji w kierunku zmniejszania presji na środowisko. Stosowanie najlepszych dostępnych technik w sektorze energetycznym wiąże się przede wszystkim z wytwarzaniem

\footnotetext{
28 Art. 3 pkt 10 u.p.o.ś.
} 
energii w źródłach odnawialnych. Wprowadzanie prośrodowiskowych systemów zarządzania procesami produkcji i usługami, polegające na systematycznej identyfikacji, a następnie konsekwentnej realizacji celów środowiskowych prowadzących do ograniczania oddziaływań na środowisko i zużywania jego zasobów proporcjonalnie do wielkości produkcji wiąże się z eksploatacją czystej energii w szerszym zakresie. Rozwój energetyki odnawialnej wiąże się ze stosowaniem technologii, dzięki której następuje: efektywne wytwarzanie energii, zapewnienie racjonalnego zużycia wody i innych surowców oraz materiałów i paliw, stosowanie technologii bezodpadowych, brak emisji albo niewielka emisja, wykorzystanie analizy cyklu życia produktów, postęp naukowo-techniczny.

Należy także wspomnieć o tym, że produkcja energii ze źródeł odnawialnych jest działaniem, które jest zgodne z prawnymi uwarunkowaniami dotyczącymi obszarów szczególnej ochrony środowiska, do których zalicza się: (1) tereny, na których występują uciążliwości lub szkodliwe uciążliwości dla środowiska; (2) obszary zdegradowane przez przemysł, rolnictwo albo inny rodzaj działalności, bądź siły przyrody; (3) tereny eksploatacji złóż kopalin, obszary o cennych walorach przyrodniczych lub krajobrazowych, tereny uzdrowisk oraz obszary związane z zaopatrzeniem w wodę. Na wymienionych obszarach obowiązują specjalne warunki gospodarczego korzystania ze środowiska i wprowadzania w nim zmian.

W przypadku ochrony powietrza istotne znaczenie mają także określone $\mathrm{w}$ art. 92 u.p.o.s. uprawnienie wojewody dotyczące wydawania, w drodze rozporządzenia, w przypadku ryzyka występowania przekroczeń dopuszczalnych lub alarmowych poziomów substancji w powietrzu, planu działań krótkoterminowych. Plan taki może w rezultacie negatywnie wpłynąć na rozwój energetyki konwencjonalnej na terenach, na których występuje przekroczenie dopuszczalnych lub alarmowych poziomów substancji i w konsekwencji przyczynić się do preferowania produkcji czystej energii. Ponadto zgodnie $\mathrm{z}$ art. 96 u.p.o.ś. wojewoda może, $w$ drodze rozporządzenia, w celu zapobieżenia negatywnemu oddziaływaniu na środowisko lub na zabytki określić dla terenu województwa bądź jego części rodzaje lub jakość paliw dopuszczonych do stosowania, a także sposób realizacji i kontroli tego obowiązku. Tym samym wojewoda ma de facto uprawnienie do ograniczenia wykorzystania paliw kopalnych na rzecz paliw odnawialnych.

\section{Projekt ustawy o racjonalnym wykorzystaniu odnawialnych zasobów energii}

Należy także nadmienić, że w dniu 23 maja 2002 roku do Sejmu wpłynął poselski projekt ustawy o racjonalnym wykorzystaniu odnawialnych zasobów energii $^{29}$ (dalej także w skrócie: projekt OZE). Głównym celem projektowanej ustawy

29 Zob. druk sejmowy nr 905. 
było umożliwienie wzrostu stopnia wykorzystania źródeł energii odnawialnej, zwłaszcza na poziomie inwestycji lokalnych realizowanych przez jednostki samorządu terytorialnego. W ocenie projektodawców ustawy istotą rozwoju energetyki odnawialnej powinny być lokalne rynki wykorzystania źródeł energii odnawialnej. System ten powinien opierać się o regulację nakazującą władzom lokalnym sporządzanie ocen odnawialnych zasobów energii, na poziomie gminnym, powiatowym i wojewódzkim. Po zidentyfikowaniu zasobów odnawialnych uruchamiany byłby proces ich wykorzystania, tzn. j.s.t. zobowiązane bylyby do "stopniowego zastępowania energii cieplnej, elektrycznej i mechanicznej pochodzącej z kopalin palnych energią czystą pochodzącą z zasobów odnawialnych istniejących na ich terenie"30, zaś podmioty gospodarcze odpowiedzialne za dystrybucję energii zobowiązane byłyby do zakupu energii ze źródeł odnawialnych w pierwszej kolejności ${ }^{31}$. Wykorzystanie odnawialnych źródeł energii wspomagane byłoby środkami publicznymi.

Zdaniem autora, mimo pozytywnego założenia samej koncepcji leżącej u podstaw projektu ustawy, tj. promocji rozwoju wykorzystania odnawialnych źródeł energii, zaproponowane $w$ nim rozwiązania legislacyjne byłyby trudne do zharmonizowania $z$ istniejącym systemem przepisów prawno-finansowych odnoszących się do odnawialnych źródeł energii. Należy podzielić sformułowane przez M. Sobolewskiego uwagi krytyczne odnoszące się do projektowanej ustawy ${ }^{32}$. Po pierwsze, projekt traktuje energetykę odnawialną wyłącznie od strony podaży (zasobów) a nie od strony popytu (odbiorców i technologii ją wykorzystujących). Podejście zaprezentowane $\mathrm{w}$ projekcie ustawy kontrastuje z unijnymi rozwiązaniami dotyczącymi energetyki odnawialnej, które skupiają się na zapewnieniu ekonomicznie uzasadnionych dla inwestora warunków zbycia wyprodukowanej energii. Po drugie, wiele sformułowań projektu ma charakter nazbyt ogólny, np. przepisy zobowiązujące gminy do zastępowania energii konwencjonalnej przez OZE, nie określają precyzyjnie w jakich sytuacjach gminy miałyby podejmować tego typu działania oraz co działoby się w przypadku, gdyby tego obowiązku nie realizowały. Po trzecie, projekt nie precyzuje wielu kwestii, np. regulujących podłączenia instalacji OZE do sieci energetycznych, obowiązku podłączenie do sieci ciepłowniczych i zakresu takiego obowiązku. Po czwarte, projekt ustawy nie precyzuje jak będzie uregulowana kwestia zakupu energii z OZE przez przedsiębiorstwa energetyczne ani nie przewiduje żadnych mechanizmów, które taką procedurę mogłyby ustalic ${ }^{33}$.

Art.9 projektu OZE.

31 Art.10 projektu OZE.

32 M. SoBoLEwsKI, Opinia merytoryczna na temat projektu ustawy o racjonalnym wykorzystaniu odnawialnych zasobów energii, (druk sejmowy nr 905), mat. BSiE Kancelarii Sejmu RP, Warszawa 2002.

33 Zob. także uwagi krytyczne: P. KRAWCZYK, Opinia prawna do poselskiego projektu ustawy o racjonalnym wykorzystaniu odnawialnych źródeł energii, (druk sejmowy nr 905), mat.BSiE Kancelarii Sejmu, Warszawa 2002. 
Zdaniem autora, obecnie obowiązujące przepisy prawne odnoszące się do odnawialnych źródeł energii stwarzają wystarczające podstawy prawno-finansowe do rozwoju wykorzystania tych źródeł, zarówno przez jednostki samorządu terytorialnego dla potrzeb gospodarki komunalnej, jak i też przez przedsiębiorców. Wydaje się, że przenoszenie tych regulacji do odrębnej ustawy nie wpłynie w istotny sposób na ulepszenie istniejącego systemu, gdyż aktualnie można inwestować w OZE bez żadnych przeszkód formalnych, uzyskując na te cele również wsparcie z funduszy publicznych.

\section{Możliwości wykorzystania odnawialnych źródeł energii w komunalnej gospodarce energetycznej}

Idea wykorzystania odnawialnych źródeł energii jest związana z filozofią zasady zrównoważonego rozwoju, której jednym z elementów jest racjonalne gospodarowanie przez człowieka zasobami naturalnymi. Oznacza to m.in. promowanie wykorzystania zasobów odnawialnych ${ }^{34}$. T.Żylicz podkreśla, że trwały i zrównoważony rozwój powinien wiązać się z istotnym ograniczeniem ingerencji człowieka w środowisko naturalne, co powinno przyczyniać się do zachowania zasobów naturalnych dla przyszłych pokoleń, bez konieczności obniżana poziomu dobrobytu społeczeństwa ${ }^{35}$. Korzystanie $\mathrm{z}$ odnawialnych źródeł energii mieści się w tej filozofii i przyczynia się nie tylko do polepszenia stanu środowiska naturalnego i zagwarantowania społeczeństwu globalnemu korzystanie z czystego środowiska, ale również przyczynia się do zachowania jego zasobów dla przyszłych pokoleń. Rozwój energetyki odnawialnej jest jedną z najbardziej oczywistych pochodnych refleksji nad prawem człowieka do życia w czystym środowisku naturalnym ${ }^{36}$ oraz obowiązkiem racjonalnego gospodarowania zasobami naturalnymi ${ }^{37}$, towarzyszącej od początku lat siedemdziesiątych ubiegłego stulecia rozwojowi cywilizacyjnemu.

Podstawowym dokumentem programowym dotyczącym energetyki odnawialnej jest Strategia Rozwoju Energetyki Odnawialnej uchwalona przez Sejm 5 września 2001 r. w związku z realizacją obowiązku wynikającego z Rezolucji Sejmu Rzeczypospolitej Polskiej z dnia 8 lipca 1999 r. w sprawie wzrostu wykorzystania energii ze źródeł odnawialnych. Wzrost zapotrzebowania na energię, spowodowany szybkim rozwojem gospodarczym, ograniczona ilość zasobów kopalnych,

\footnotetext{
${ }^{34}$ Zob. H. Lisicka, J. Sommer, Przyszlość odnawialnych źródel energii w świetle polityki energetycznej państwa, Ochrona Srodowiska, Prawo i Polityka, Nr 4/2002, s. 2 i n.

35 Zob. T. ŻyuIcz, Polityka trwałego rozwoju a efektywność energetyczna, Energia, Pieniądze i Środowisko, Numer specjalny 2001, s. 29 i n.

36 V. KARTASHKIN, Economic, social and cultural rigts, [w:] The international dimensions of human rights, Volume 1, K.Vasak (red.), Paris 1982, s. 124 i n.

37 K. Dziadosz Racjonalność ekologiczna w prawie i polityce, Olsztyn 2000, s. 47 i n.
} 
a także nadmierne zanieczyszczenie środowiska, spowodowały w ostatnich latach, duże zainteresowanie odnawialnymi źródłami energii ${ }^{38}$. Udział odnawialnych źródeł energii w bilansie paliwowo-energetycznym świata wynosi około $18 \%$, wielkość ta wynika zarówno z rozwoju nowych technologii wykorzystujących odnawialne źródła energii jak również z faktu, że część ludności świata nie ma dostępu do konwencjonalnych źródeł energii. Wspieranie rozwoju odnawialnych źródeł energii stało się ważnym celem polityki Unii Europejskiej ${ }^{39}$. Wyrazem tego stała się opublikowana w 1997 roku, w Białej Księdze Komisji Europejskiej ${ }^{40}$, strategia rozwoju odnawialnych źródeł energii w krajach Unii Europejskiej, która została uznana za podstawę działań na poziomie unijnym ${ }^{41}$. Ilościowe oszacowanie wykorzystania energii odnawialnej w Polsce jest obecnie rzeczą bardzo trudną, ponieważ informacje na ten temat są dostępne jedynie za pośrednictwem specjalnych badań ankietowych ${ }^{42}$. Istnieją także znaczne rozbieżności w ocenie potencjału technicznego odnawialnych źródeł energii występujących w Polsce. Zgodnie z ekspertyzą Europejskiego Centrum Energii Odnawialnej pt. Ekonomiczne i prawne aspekty wykorzystania odnawialnych źródeł energii w Polsce ${ }^{43}$, rzeczywisty potencjał techniczny odnawialnych źródeł energii w Polsce wynosi około 2514 PJ/rok co stanowi prawie $60 \%$ krajowego zapotrzebowania na energię pierwotną.

38 Zob. Strategia Rozwoju Energetyki Odnawialnej, dokument opracowany w 2000 r. przez Ministerstwo Środowiska i przyjęty przez Radę Ministrów w dniu 5 września 2000 r. oraz przez Sejm Rzeczypospolitej Polskiej w dniu 23 sierpnia 2001 r. Dokument ten jest wypełnieniem obowiązku wynikającego z Rezolucji Sejmu Rzeczypospolitej Polskiej z dnia 8 lipca 1999r w sprawie wzrostu wykorzystania energii ze źródeł odnawialnych (M.P. z 1999 r. Nr 25, poz.365).

39 Przygotowując model energetyczny, w ramach instytucji UE wykonano szereg badań, symulacji i analiz, m.in. w ramach programu JOULE II, SAFIRE $\mathrm{i}$ TERES II.

40 Zob. Komunikat Komisji: Energia dla przyszłości: Odnawialne źródła energii - Biała Księga o strategii i planie działania Wspólnoty (COM(97) 559 final); Rezolucja Rady z dnia 8 czerwca 1998 roku w sprawie odnawialnych źródeł energii (OJ C 198, z dnia 24.06.1998 r.): Rezolucja Parlamentu Europejskiego w sprawie powyższego Komunikatu Komisji (A4-0207/98).

${ }^{41}$ Mając na względzie konieczność monitoringu wdrażania unijnej polityki rozwoju odnawialnych źródeł energii, w ramach programu ALTENER zrealizowano projekt znany pod nazwą PRETIR (Progress of Renewable Energy: Target setting, Implementation and Realisation). Celem projektu były przegląd i ocena ex ante efektywności instrumentów wspierających rozwój i wdrażanie OZE stosowanych przez kraje UE. Tym samym projekt ten należy traktować jako ocenę szans osiągnięcia przez poszczególne państwa członkowskie, jak i przez całą Unię, celów ilościowych wskazanych w wyżej wymienionych dokumentach.

42 Przykładowo w roczniku statystycznym Gospodarka paliwowo-energetyczna w latach 1997-98 (GUS 1999) udział źródeł pozostałych (tzn. drewno opałowe, torf, paliwa odpadowe, energia wodna i inne nośniki odnawialne) w zużyciu energii pierwotnej w 1997 roku został określony na około 4,06\%, zgodnie $\mathrm{z}$ dokumentem Załozenia polityki energetycznej Polski do 2020 roku paliwa odnawialne w strukturze zużycia energii pierwotnej w 1997 roku stanowily 5,1\%. Natomiast w ekspertyzie Europejskiego Centrum Energii Odnawialnej Ekonomiczne i prawne aspekty wykorzystania odnawialnych źródeł energii w Polsce, (EC BREC 2000) szacuje się, że udział energii ze źródeł odnawialnych wynosi 2,5\%

${ }_{43}$ Zob. ekspertyza Europejskiego Centrum Energii Odnawialnej, Ekonomiczne i prawne aspekty wykorzystania odnawialnych źródeł energii w Polsce, Warszawa 2000. 
Światowa Komisja Rady Energetycznej przewiduje do roku 2020 wzrost udziału energii odnawialnej w zależności od scenariusza rozwoju do 21,3\% (scenariusz pesymistyczny) lub nawet do $29,6 \%$ (scenariusz optymistyczny). Z prac prognostycznych wykonanych przez polskich specjalistów wynika, że w 2010 roku w Polsce udział energii odnawialnej w zużyciu energii pierwotnej będzie wynosił od $5,06 \%$ do 5,74\% w zależności od przyjętego scenariusza makroekonomicznego. W Założeniach Polityki Energetycznej Polski do roku 2025 przyjmuje się, że całkowite zapotrzebowanie na energię w roku 2010, dla scenariusza odniesienia, wyniesie 4570 PJ. Przy wyżej założonym zapotrzebowaniu na energię w roku 2010, uzyskanie 7,5\% udziału energii ze źródeł odnawialnych w bilansie energii pierwotnej oznacza konieczność wyprodukowania w 2010 r. ok. 340 PJ energii ze źródeł odnawialnych, co oznacza zwiększenie w stosunku do roku 1999 zdolności produkcyjnych w sektorze energetyki odnawialnej o dodatkowe ok. 235 PJ. Uzyskanie takiej zdolności produkcyjnej oznacza konieczność zrealizowania w ciągu dziesięciu lat szeregu inwestycji z zakresu wykorzystania poszczególnych źródeł energii odnawialnej oraz odpowiedni wzrost nakładów inwestycyjnych.

Punktem wyjścia do określenia niezbędnych nakładów inwestycyjnych i towarzyszącego im wsparcia ze środków publicznych jest zdefiniowanie udziału poszczególnych technologii wykorzystujących odnawialne źródła energii w ramach wszystkich inwestycji planowanych do realizacji do roku 2010 i pozwalających na wyprodukowanie ok. 340 PJ energii ze źródeł odnawialnych ogółem. Na podstawie wspomnianej wcześniej ekspertyzy Ekonomiczne i prawne aspekty wykorzystania odnawialnych źródeł energii w Polsce oraz oszacowań eksperckich, zostały przygotowane trzy scenariusze rozwoju, zakładające stosowne przyrosty mocy zainstalowanej w poszczególnych grupach technologii wykorzystujących odnawialne źródła energii, ale różniące się udziałem energii elektrycznej produkowanej ze źródeł odnawialnych: (1) scenariusz 7,5\% - zakładający udział energii elektrycznej produkowanej ze źródeł odnawialnych na poziomie 7,5\% całkowitej produkcji energii elektrycznej w Polsce w roku 2010 i odpowiednio (2) scenariusz $9 \%$ oraz (3) scenariusz 12,5\%. W zaproponowanej konfiguracji technologii, wymagane nakłady inwestycyjne do roku 2010 wyniosą dla każdego ze scenariuszy odpowiednio (ceny roku 1999 r.): (1) wariant 7,5\% - $14508 \mathrm{mln}$ zl; (2) wariant 9\% - 15263 mln zl; (3) wariant 12,5\% - 19103 mln zl.

Opierając się o definicję odnawialnego źródła energii zawartą w art. 3 pkt 20 u.p.e. można stwierdzić, że ustawowy obowiązek zakupu lub wytwarzania energii elektrycznej w odnawialnym źródle energii będzie spełniony przy wykorzystaniu następujących technologii: (1) kotłów na drewno: (a) obsługiwanych ręcznie, o małej mocy, (b) ciepłowni automatycznych, o większej mocy; (2) kotłów na słomę: (a) obsługiwanych ręcznie, o małej mocy, (b) ciepłowni automatycznych, o większej mocy; (3) biogazowni rolniczych (surowiec w postaci gnojowicy), (4) biogazowni komunalnych (surowiec w postaci osadu ściekowego) produkujących 
ciepło i energię elektryczną,); (5) instalacji wykorzystania gazu wysypiskowego: (a) do produkcji energii elektrycznej, (b) do współwytwarzania ciepła i elektryczności, (6) kolektorów słonecznych: (a) do podgrzewania wody użytkowej, (b) do podgrzewania powietrza; (7) systemów fotowoltanicznych; (8) elektrowni wiatrowych sieciowych: (a) małej i średniej mocy, (b) dużej mocy, (9) małych elektrowni wodnych: (a) odbudowywanych na istniejącym jazie, (b) budowanych od podstaw; (10) ciepłowni geotermalnych.

Obecnie podstawowym źródłem energii odnawialnej wykorzystywanym w kraju jest biomasa oraz energia wodna, natomiast energia geotermalna, wiatru, promieniowania słonecznego, ma mniejsze znaczenie.

Największe nadzieje na wykorzystanie, jako odnawialne źródło energii, są wiązane z biomasą. Biomasa może być używana na cele energetyczne w procesach bezpośredniego spalania biopaliw stałych (drewna, słomy), gazowych w postaci biogazu lub przetwarzana na paliwa ciekłe (olej, alkohol), będąc obiecującym źródłem energii odnawialnej w Polsce ${ }^{44}$.

Kolejnym źródłem energetycznym jest biogaz. Główny potencjał techniczny gazu wysypiskowego w Polsce związany jest $z$ największymi, składowiskami odpadów komunalnych. Obecnie technologie energetycznego wykorzystania gazu wysypiskowego (głównie do produkcji energii elektrycznej lub w skojarzeniu z produkcją energii cieplnej) należą do najszybciej rozwijających się gałęzi energetyki odnawialnej na świecie. Potencjał techniczny wykorzystania biogazu z oczyszczalni ścieków do celów energetycznych jest również bardzo wysoki. Do bezpośredniej produkcji biogazu najlepiej dostosowane są oczyszczalnie biologiczne, stosowane we wszystkich oczyszczalniach ścieków komunalnych oraz w części oczyszczalni przemysłowych.

Znaczący jest także potencjał techniczny biopaliw ciekłych otrzymanych $z$ konwersji biomasy, takich jak benzyna $z$ dodatkiem etanolu jak i paliwo otrzymywane z tłuszczów roślinnych lub zwierzęcych. Obecnie zgodnie z polskimi normami, etanol może stanowić jedynie 5\% dodatek do paliwa tradycyjnego. Do produkcji alkoholu etylowego można stosować: zboże, ziemniaki, buraki, melasę. Od roku 1996 produkcja bioetanolu (odwodnionego alkoholu etylowego pochodzenia roślinnego) prawie w całości wykorzystywana jest do celów przemysłowych jako dodatek do paliw ${ }^{45}$.

${ }^{44}$ Żródło www.kape.gov.pl. Zob. na ten temat G. Wiśniewski, M. PisareK, L. Łakomiec, Wstępne badania $i$ analizy w zakresie wykorzystania zrębków drzewnych z procesów pielęgnacji terenów zielonych na cele energetyczne, mat. z Ogólnopolskiego Forum Odnawialnych Żródeł Energii, Gdańsk 1998.

${ }_{45}$ Zasady wytwarzania, magazynowania i obrót biokomponentami stosowanymi w paliwach ciekłych i biopaliwach ciekłych, zasady wykorzystywania surowców rolniczych do wytwarzania biokomponentów, obowiązki i zasady odpowiedzialności podmiotów wprowadzających do obrotu biokomponenty, wymagania jakościowe dla biokomponentów oraz zasady monitorowania 
Największe tradycje ma w Polsce energetyka wodna. Energetyczne zasoby wodne Polski są niewielkie ze względu na niezbyt obfite i niekorzystnie rozłożone opady, dużą przepuszczalność gruntów i niewielkie spadki terenów. Praktycznie jedynymi obiektami hydroenergetycznymi, których ilość stale wzrasta, głównie za sprawą inwestorów prywatnych, są małe elektrownie wodne (o zainstalowanej mocy poniżej $500 \mathrm{~kW}$ ), budowane przeważnie na istniejących stopniach wodnych.

Kolejnym odnawialny źródłem energii są wody geotermalne. W ostatnich latach w kraju zostały przeprowadzone badania mające na celu określenie możliwości wykorzystania wód geotermalnych do celów grzewczych. O ile potencjał techniczny wód geotermalnych został dokładnie zbadany to należy zauważyć, że istnieje potrzeba prowadzenia dalszych badań w zakresie odprowadzenia do górotworu wykorzystanych wód geotermalnych ${ }^{46}$.

rynku biokomponentów, reguluje ustawa $z$ dnia 2 października 2003 r. o biokomponentach stosowanych w paliwach ciekłych i biopaliwach ciekłych (Dz. U. z $2003 \mathrm{r}$. Nr 199, poz. 1934). Zgodnie $z$ definicjami zawartymi $w$ tej ustawie: (1) biokomponenty oznaczają - ester lub bioetanol, w tym bioetanol zawarty w eterze etylo-tert-butylowym lub eterze etylo-tert-amylowym oraz estry stanowiące samoistne paliwa silnikowe; (2) ester oznacza- estry metylowe albo estry etylowe wyższych kwasów tłuszczowych otrzymane w procesie przetwarzania rzepaku albo produktów ubocznych i odpadów; (3) bioetanol oznacza - odwodniony alkohol etylowy rolniczy produkowany z surowców rolniczych lub produktów ubocznych i odpadów; (4) paliwa ciekłe oznacza - benzyny silnikowe stosowane w pojazdach wyposażonych w silniki z zapłonem iskrowym, zawierające w swoim składzie do $5 \%$ bioetanolu oraz do $15 \%$ eterów, samochodowe oleje napędowe zawierające do $5 \%$ estrów, stosowane w pojazdach wyposażonych $w$ silniki z zaplonem samoczynnym, spełniające wymagania jakościowe określone dla paliw ciekłych w odrębnych przepisach; (5) biopaliwa ciekłe oznacza - estry stanowiące samoistne paliwa silnikowe, benzyny silnikowe zawierające w swoim składzie powyżej $5 \%$ bioetanolu oraz powyżej $15 \%$ eterów, oleje napędowe zawierające powyżej 5 \% biokomponentów, spełniające wymagania jakościowe określone dla paliw ciekłych w odrębnych przepisach.

${ }^{46}$ Zob. szerzej B. KĘPIŃsKa, Energia geotermalna w Polsce - stan obecny i perspektywy wykorzystania, [w:] Energia geotermalna w kopalniach podziemnych, Z.Małolepszy (red.), Sosnowiec 2002; I. WINDER, Wykorzystanie zasobów energii geotermalnej przynosi korzyści, Gazeta Samorządu i Administracji, Nr 4/5(152/153)/2004; Energia Geotermalna w Polsce. Ocena mozliwości wykorzystania energii geotermalnej, Raport Ministerstwa Środowiska, Warszawa 2000; Zasady dofinansowania ze środków publicznych przedsięwzięć zwiq̨anych z rozwojem geotermii w Polsce, mat. Ministerstwa Środowiska, Warszawa 2003 oraz następujące opracowania: (1) Studium pt: Ocena możliwości wykorzystania istniejących odwiertów w Polsce Poludniowej i Poludniowo Zachodniej dla odzysku energii geotermalnej (pr.zbior. pod kier. D. Poprawy i B. Mroczkowskiej), 1996; (2) Studium możliwości inwestycyjnych nad wykorzystaniem energii geotermalnej w zbiornikach dolnojurajskim $i$ dolnokredowym w synklinorium mogileńsko-łódzkim na Niżu Polskim, (pr. zbior. pod kier. W. Góreckiego i T. Kuźniaka), Kraków 1996; (3) Dokumentacja hydrogeologiczna wód termalnych niecki podhalańskiej, (pr.zbior.: J. Chowaniec, P. Długosz, B. Drozdowski, St. Nagy, D. Poprawa, S. Witczak, K. Witek, Państwowy Instytut Geologiczny-Oddział Karpacki i „Geotermia Podhalańska", 1996); (4) Dokumentacja hydrogeologiczna zasobów eksploatacyjnych ujęcia wód termalnych z utworów jury dolnej w Skierniewicach, (pr.zbior. A. Bentkowski, H. Biernat, K. Bujakowska, J. Kapuściński, Przedsiębiorstwo Geologiczne w Warszawie-Polgeol; 1998); (5) Studium możliwości inwestycyjnych nad wykorzystaniem energii geotermalnej w zbiorniku mezo- 
Energetyka wiatrowa w naszym kraju zaczęła rozwijać się dopiero na początku lat dziewięćdziesiątych, głównie na wybrzeżu. Rejonami najbardziej uprzywilejowanymi do wykorzystania energii wiatru są Wybrzeże Morza Bałtyckiego, Suwalszczyzna i Równina Mazowiecka. Obserwuje się duże zainteresowanie inwestorów instalacjami wiatrowymi, szczególnie w północno-zachodniej Polsce. Energetyka słoneczna jest najmniej rozpowszechnioną w Polsce formą energii. Warunki meteorologiczne w Polsce charakteryzują się bardzo nierównym rozkładem promieniowania słonecznego w cyklu rocznym, ok. 80\% całkowitej rocznej sumy nasłonecznienia przypada na sześć miesięcy sezonu wiosenno-letniego. Ogniwa fotowoltaniczne, w których dokonuje się konwersji promieniowania słonecznego na energię elektryczną praktycznie nie są w Polsce użytkowane.

\section{Wnioski}

Reasumując należy stwierdzić, że wykorzystanie odnawialnych źródeł energii, w szczególności w komunalnej gospodarce energetycznej, przyczynia się do osiągania znaczących efektów ekologicznych, przede wszystkim poprzez redukcję emisji gazów cieplarnianych, jak i też sprzyja osiąganiu efektów społeczno-gospodarczych takich jak: (1) tworzenie dodatkowych miejsc pracy, gdyż zatrudnienie przy produkcji i obsłudze urządzeń i linii technologicznych, przy produkcji i przygotowaniu biopaliw, w obsłudze przedsiębiorstw inwestujących w OZE, daje kilkukrotnie więcej miejsc pracy niż w energetyce tradycyjnej; (2) obniżanie kosztów użytkowania energii elektrycznej i cieplnej przez odbiorców; (3) rozwój branży wykonawczej i produkcyjnej związanej z inwestycjami w odnawialne źródła energii. $Z$ tego też względu warto uwzględniać w lokalnych strategiach rozwoju promocję tego typu inwestycji, gdyż działania tego rodzaju wypełniają dyspozycję konstytucyjnej zasady zrównoważonego rozwoju.

zoicznym e niecce szczecińskiej i pólnocnej części monokliny przedsudeckiej, (pr. zbior. pod kier. J. Sokołowskiego, PAN, Kraków 1998); (6) Modele geotermalne formacji mezozoicznej na obszarze niecki warszawskiej konstruowane z wykorzystaniem systemu Landmark i studium techniczno-ekonomiczne, (pr. zbior. pod kier. W.Góreckiego i J.Kuźniaka, Akademia Górniczo-Hutnicza w Krakowie, 1998). 


\section{Aspects of Financial Law as regards the use of renewable energy in Poland in the context of conformity to constitutional principles for stable development}

SUMMARY

The article describes the use renewable sources of energy particularly with regard to National Energy Policy in order to achieve good ecological results, principally through the reduction of the use of Greenhouse gases.

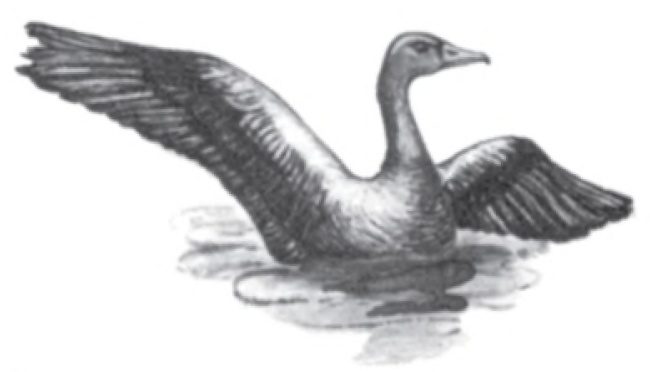

Gęgawa 